\title{
Commentary Surfactant for acute respiratory failure in children: where should it fit in our treatment algorithm?
}

\author{
Margrid Schindler
}

Paediatric Intensive Care Unit, Bristol Royal Hospital for Children, Upper Maudlin Street, Bristol BS2 8BJ, UK

Corresponding author: Margrid Schindler, Margrid.Schindler@ubht.nhs.uk

Published: 19 July 2007

This article is online at http://ccforum.com/content/11/4/148

(c) 2007 BioMed Central Ltd

See related research by Duffett et al., http://ccforum.com/content/11/3/R66
Critical Care 2007, 11:148 (doi:10.1186/cc5951)

\begin{abstract}
In a recent meta-analysis, surfactant administration in paediatric acute respiratory failure was associated with improved oxygenation, reduced mortality, increased ventilator-free days and reduced duration of ventilation. Surfactant is expensive, however, and its use involves installation of large volumes into the lungs, resulting in transient hypoxia and hypotension in some patients. Many questions also remain unanswered, such the as optimum dosage and the timing of administration of surfactant. The merits of surfactant administration should therefore still be decided on an individual case-by-case basis.
\end{abstract}

Duffett and colleagues performed a meta-analysis of the six published randomised trials of surfactant therapy in intubated and ventilated children with acute respiratory failure [1]. In all six trials, involving a total of 314 patients, surfactant administration was associated with beneficial effects, including improved oxygenation, reduced mortality, increased ventilator-free days and reduced duration of ventilation.

The meta-analysis provides strong evidence for the use of surfactant in acute respiratory failure in children, but where should it fit in our treatment algorithm?

Optimising the ventilation settings remains the important initial step in management of acute respiratory failure in children requiring intubation. Ensuring that an appropriate tidal volume $(6 \mathrm{ml} / \mathrm{kg})$ is used is important to avoid exacerbating the lung injury with excessive tidal volumes [2]. In addition, an appropriate positive end-expiratory pressure, a longer inspiratory time, permissive hypercapnia and accepting lower oxygen saturations (85-94\%) should be attempted.

If the above therapies do not work, we are then faced with a number of options, including surfactant, high-frequency oscillatory ventilation, steroids, and inhaled nitric oxide. But in what order should we use these options?
Using evidence-based medicine, the evidence is strongest for the use of surfactant. Next favoured would be steroids, which have been shown to improve oxygenation, to shorten the duration of mechanical ventilation and to reduce the multiorgan failure score in two randomised trials in adults $[3,4]$; this therapy would then be followed by high-frequency oscillatory ventilation, which reduced the oxygen requirement in survivors in the one published randomised trial in children [5]. Inhaled nitric oxide would rank last in this list as, although it improved oxygenation in the first 24 hours, its use has not been associated with any significant change in any other outcome marker [6].

The use of surfactant in paediatric patients, especially larger children, however, is expensive and requires instillation of large volumes of surfactant into the lungs. With the current financial restraints facing most intensive care units, the more frequent use of surfactant would have large financial implications. Each $8 \mathrm{ml}$ vial of Survanta (Abbott Laboratories, Maidenhead, Berks, UK) used in our institution costs $£ 300$, thus the administration of a single dose in a larger patient could cost thousands of pounds. Similarly, the use of inhaled nitric oxide is expensive, with 3 days of treatment costing $£ 3,000$. From the financial point of view, therefore, high-frequency oscillatory ventilation and steroids would rank more favourably.

What about the risks of each of the treatments? Highfrequency oscillatory ventilation and inhaled nitric oxide use have not been associated with any significant increase in the rates of adverse events [5,6]. Surfactant use was also not associated with any serious adverse events; however, transient hypotension and transient hypoxia did occur in some patients [1]. Methylprednisolone use was associated with a significant increase in 60-day and 180-day mortality when patients were enrolled at least 14 days after the onset of the acute respiratory failure. Methylprednisolone was also associated with a higher rate of neuromuscular weakness [4]. 
The ranking of these treatments is therefore difficult and depends on which aspect is examined.

The next question is whether some patient groups respond more favourably to one treatment or another. Three of the randomised trials reported in this meta-analysis only involved infants with viral bronchiolitis, who responded well to surfactant [1]. Only three of the trials involved older children with acute lung injury from a variety of causes. All of the trials except that of Tibby and colleagues excluded patients with chronic lung disease [7]. Only one trial enrolled patients with cardiac disease or uncorrected congenital heart disease [8]. More studies are required in these patient groups.

Another issue is the optimum dosage and the timing of surfactant treatment. Surfactant was used within the first 24-48 hours of intubation in three trials $[7,9,10]$, and within the first 5 days in another [8]. The timing of surfactant use was not stated in the remaining two trials [11]. Patients with milder degrees of hypoxia (oxygenation index 5-7) were enrolled in three of the studies $[7,9,10]$. Moller and colleagues also observed a better response if the $\mathrm{PaO}_{2} / \mathrm{FiO}_{2}$ ratio was greater than 65 [8], again suggesting a better response if surfactant is used early in less hypoxic patients.

Four of the six trials used $100 \mathrm{mg} / \mathrm{kg}$ phospholipids [7-10]. The remaining two trials performed by the same author used $50 \mathrm{mg} / \mathrm{kg}$ phospholipids in infants with viral bronchiolitis [11]. Further trials are required to determine whether smaller doses of surfactant are effective in nonbronchiolitis patients.

Despite the apparently good evidence for the benefit of surfactant in paediatric patients with hypoxic respiratory failure, therefore, many questions remain unanswered - such as the optimum timing of administration, what dose to use and which patient groups are most suitable. We still need to weigh up the pros and cons of using surfactant in each individual patient to decide whether the surfactant benefits outweigh the financial implications and risks in that particular patient.

\section{Competing interests}

The author declares that they have no competing interests.

\section{References}

1. Duffett M, Choong K, Ng V, Randolph A, Cook DJ: Surfactant therapy for acute respiratory failure in children: a systematic review and meta-analysis. Crit Care 2007, 11:R66.

2. ARDS Network: Ventilation with lower tidal volumes as compared with traditional tidal volumes for acute lung injury and the acute respiratory distress syndrome. N Engl J Med 2000, 342:1301-1308.

3. Meduri GU, Golden E, Freire AX, Taylor E, Zaman M, Carson SJ, Gibson M, Umberger R: Methylprednisolone infusion in early severe ARDS: results of a randomized controlled trial. Chest 2007, 131:954-963.

4. Steinberg KP, Hudson LD, Goodman RB, Hough CL, Lanken PN, Hyzy R, Thompson BT, Ancukiewicz M: Efficacy and safety of corticosteroids for persistent acute respiratory distress syndrome. N Engl J Med 2006, 354:1671-1684.
5. Arnold JH Hanson JH, Toro-Figuero LO, Gutierrez J, Berens RJ, Anglin DL: Prospective, randomised comparison of high-frequency oscillatory ventilation and conventional mechanical ventilation in pediatric respiratory failure. Crit Care Med 1994, 22:1530-1539.

6. Adhikari NK, Burns KE, Friedrich JO, Granton JT, Cook DJ, Meade MO: Effect of nitric oxide on oxygenation and mortality in acute lung injury: systematic review and meta-analysis. $\mathrm{Br}$ Med J 2007, 334:779-782.

7. Tibby SM, Hatherill M, Wright SM, Wilson P, Postle AD, Murdoch IA: Exogenous surfactant supplementation in infants with respiratory syncytial virus bronchiolitis. Am J Respir Crit Care Med 2000, 162:1251-1256.

8. Moller JC, Schaible T, Roll C, Schiffmann JH, Bindl L, Schrod L Reiss I, Kohl M, Demirakca S, Hentschel R, et al:: Treatment with bovine surfanctant in severe acute respiratory distress syndrome in children: a randomized multicenter study. Intensive Care Med 2003, 29:437-446.

9. Willson DF, Thomas NJ, Markovitz BP, Bauman LA, DiCarlo JV, Pon S, Jacobs BR, Jefferson LS, Conaway MR, Egan EA: Effect of exogenous surfactant (calfactant) in pediatric acute lung injury: a randomized controlled trial. J Am Med Assoc 2005, 293:470-476.

10. Willson DF, Jin Hua J, Bauman LA, Zaritsky A, Craft H, Dockery K, Conrad D, Dalton $\mathrm{H}$ : Calf's lung surfactant extract in acute hypoxemic respiratory failure in children. Crit Care Med 1996, 24:1316-1322.

11. Luchetti M, Ferrero F, Gallini C, Natale A, Pigna A, Tortorolo L Marraro G: Multicenter, randomised, controlled study of porcine surfactant in severe respiratory syncytial virusinduced respiratory failure. Pediatr Crit Care Med 2002, 3: 261-268. 